$$
\begin{gathered}
\text { 全身性エリテマトーデス患者血清中の } \\
\text { 可溶性インターロイキン } 2 \text { レ プター }(\mathrm{IL}-2 \mathrm{R}) \\
\text { 戸叶 嘉明・関 川 嚴 } \\
\text { 橋 本 博史・奥 村 康*・廣瀬 俊 - }
\end{gathered}
$$

Jpn. J. Clin. Immun., 11(6):559 565, 1988 .

\title{
Soluble interleukin-2 receptor in sera of patients with systemic lupus erythematosus
}

Yoshiaki Tokano, Iwao Sekigawa, Hiroshi Hashimoto, Ko Okumura* and Shunichi Hirose

\begin{abstract}
Department of Internal Medicine (Rheumatology of Internal Medicine) and *Immunology, Juntendo University School of Medicine
\end{abstract}

\section{【Summary】}

\begin{abstract}
We examined soluble IL-2 $\mathrm{R}$ in sera of patients with SLE by ELISA using two monoclonal anti IL-2 $R$ antibodies. When we examined sera of forty patients with SLE, soluble IL-2 $R$ in sera of them significantly increased as compared with normal controls, (SLE ; 337.8 \pm 188.2 $\mathrm{U} / \mathrm{m} l$, Normal control; $150.0 \pm 35.0 \mathrm{U} / \mathrm{ml}$ ). Sixteen patients (40\%) had high titer of soluble IL-2 R (more than mean+2 S.D. of normal controls). And then we investigated the clinical findings of patients with high titer of soluble IL-2R. Although in these patients, the peripheral pattern of anti nuclear antibody and pericarditis appeared more frequently than patients with normal titer of soluble IL-2 R, there was no significance in anti DNA antibody, $\mathrm{CH} 50$, renal involvement (proteinuria, urine cast), skin involvement, pleuritis, central nervous system involvement, hematological findings. It is known that soluble IL- $2 \mathrm{R}$ appeared in the culture supernatant of normal peripheral blood lymphocyte stimulated by mitogen (PHA, anti OKT 3 etc.) or in sera of patients with adult $\mathrm{T}$ cell leukemia, it is said that soluble IL-2 R relate to activated $\mathrm{T}$ cells. On the other hand, although it was reported that activated $\mathrm{T}$ cells appeared in peripheral blood lymphocytes of patients with SLE, the fact that many patients with SLE had soluble $I L-2 R$ in our examination may relate to activated $T$ cells. And therefore, we confirmed them by using various activated $T$ cell marker (HLA-DR positive $T$ cell, HLA-DP positive $T$ cell, IL-2 R positive $T$ cell). The patients with high titer of soluble of IL-2 $R$ tended to have high positive rate of HLA-DP positive $T$ cells, HLA-DR positive $T$ cells, but not so much IL-2 $R$ positive $T$ cell. This results suggest the existence of
\end{abstract}


activated $T$ cells and the relationship between soluble IL-2 R and activated $T$ cells. It is said that patients with SLE have $T$ cells abnormality (ex. the decrease of mitogen response, auto mixed lymphocyte reaction, IL-2 production, IL-2 response) and activated $\mathrm{T}$ cells, and it is suggested that these abnormality related to the pathogenesis of SLE. Our results confirm the existence of activated $T$ cells, in patients with SLE and suggest the possibility that soluble IL-2 R could be used as the marker of activated $T$ cells or the new barometer of disease activity, although it is not clear how activated $T$ cells relate to pathogenesis or clinical findings of SLE. And, although the immunological role of soluble IL-2 $R$ is not clear, it may be one of clue in the investigation of pathogenesis of SLE.

Key words : SLE, soluble IL-2 receptor

\section{【概 要】}

40 例の SLE 患者の血清中可溶性 IL-2 R を ELISA 法を用いて検索した。その結果, SLE 患者の可溶性 IL-2 R は 正常人に比べ有意に増加していた. 正常人の mean+2 S.D. 以上の症例を可溶性 IL-2 R 高值群として臨床所見を検 討してみると, 高値群では心外膜炎および抗核抗体 peripheral pattern の頻度が有意に高かったが, 堅病変, 抗 DNA 抗体の力価, CH 50 の值では差がなかった．可溶性 IL-2 R は活性化T細胞が存在すると出現するといわれていること から, 可溶性 IL-2 R の力価と他の活性化 T細胞のマーカーとの関連を検討してみると, 可溶性 IL-2 R が高值の症例 では HLA-DR, HLA-DP 陽性T細胞が多い傾向にあった。これらの結果は SLE 患者における活性化T細胞の存在を 示唆すると同時に, 可溶性 IL-2 R が活性化T細胞の指標として臨床に応用できる可能性があると思われた.

\section{I.はじめに}

全身性エリテマトーデス（SLE）は高力洒の自己抗体 が多彩に出現し，多臟器障害をきたす疾患であるが，病 因はいまだ不明である。しかし，近年，自己抗体やリン パ球の解析が進み，特に細胞性免疫の分野では polyclonal B cell activation といわれるB細胞の異常が注目 されている。また， $\mathrm{T}$ 細胞についても，Leu 3a，2a 陽 性細胞数の変動など数の異常 ${ }^{1,2\}}$ や各種 mitogen に対す る反応の低下, 自己リンパ球混合培養 (AMLR) の無反 応 $^{3,4)}$, インターロイキン $2(\mathrm{IL}-2)$ 産生能の低下 ${ }^{5 \sim 7) な と ゙ ~}$ の機能異常も報告されている.さらに，HLA-DR 陽性 T細胞の出現など，活性化した $\mathrm{T}$ 細胞の存在を示唆する 報告沛もある。

一方，IL-2レセプター（IL-2R）は特に mitogen 刺 激を加えた T細胞9)や ATL の腫噋細胞の膜表面に多く 発現される ${ }^{10)}$ が, 最近これらの培荃上清あるいは血清中 に soluble IL-2 R (可溶性 IL-2R) が出現することが報 告され ${ }^{11,12)}$, 活性化 T細胞の存在を示す 1 つのマーカー と考えられるよ5になってきている. そして，IL-2 産 生能の低下や IL-2 に対する反応性の低下をみる SLE に おいては，血清中の可溶性 IL-2 R がいかなる動態を示
すのかを知ることはきわめて重要と考えられる.

我々はすでに SLE 患者の活性化T細胞を HLA-DR 抗 原の発現などを指標として検索し，臨床経過との関連を 検討してきた。しかし，この方法は手技が繁雜で，日常 のルチーン検査には適さないため，できるだけ簡易な方 法で活性化 T細胞の存在をスクリーニングできる方法が 求められてきた. 今回我々は可塎性 $\mathrm{IL}-2 \mathrm{R}$ が活性化 $\mathrm{T}$ 細胞の存在のマーカーとなりらるという報告に着目し， $\mathrm{S}_{\mathrm{LE}}$ における活性化 $\mathrm{T}$ 細胞の存在が可溶性 IL-2 R の検 索により知ることができるかどうかを検討する目的で, SLE 患者の血清中の可溶性 IL-2 R と活性化 T細胞との 関連について検討を行い,さらに臨床との関連も検討し たので報告する.

\section{II. 対象および方法}

\section{1. 対象患者}

アメリカリウマチ協会の診断基準 (1982 年)を満たす SLE 患者 40 例（男性 2 例 - 女性 38 例, 平均年踚 28.5 歳）および正常人 10 例を対象とした. SLE 患者は平均 䍜患期間約 9 年で, 平均 $14 \mathrm{mg} /$ 日のステロイドの投与 を受けていた。 


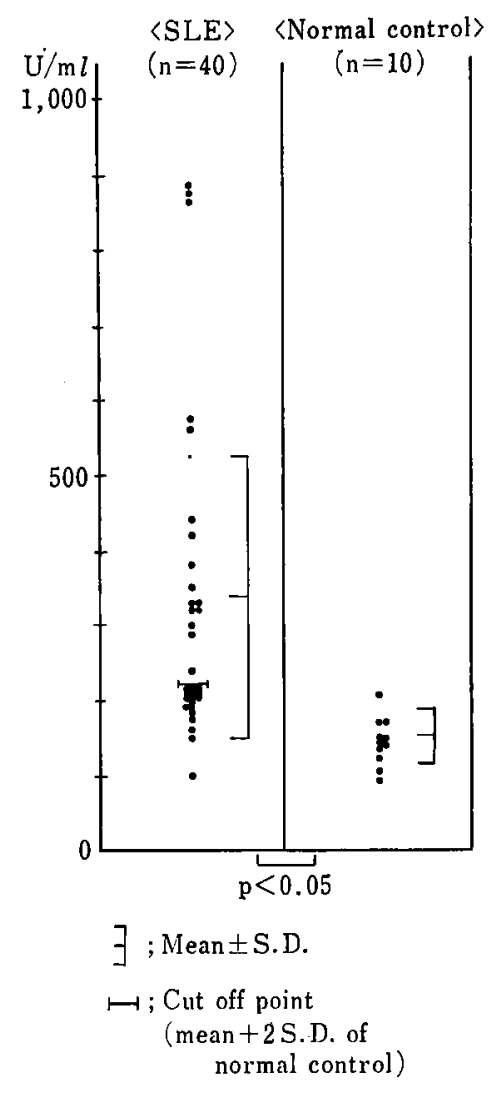

図 1 Soluble IL-2 R in sera of patients with SLE and normal controls

\section{2. 可溶性 IL-2 R の測定}

可溶性 IL-2 R の測定は T cell サイエンス社のキット を用い，以下の ELISA 法で行った.すなわち，120倍に 希釈した抗IL-2 R 抗体（抗 Tac 抗体） $100 \mu l /$ well 96 穴の multiplate に coating し $4^{\circ} \mathrm{C}$ で 48 時間 incubate した. 次に $1 \%$ Bovine serum albumin (BSA) in phosphate buffer saline (PBS) $37^{\circ} \mathrm{C}$ で 2 時間 blocking したあと， 4 倍に希䣋した血清を $100 \mu l /$ well 加え， $37^{\circ} \mathrm{C}$ で 2 時間 incubate した。さらに, coating で用い た抗体と認識するエピトープの異なるペルオキシダーゼ 標識抗 IL-2 R 抗体 (7G7/B6) を加え， $37^{\circ} \mathrm{C}$ で 2 時間 incubate したあと，O-フェニレンジアミン (O.P.D.) を 加えた. 30 分後, $2.5 \mathrm{M} \mathrm{H}_{2} \mathrm{SO}_{4}$ で反応を止め, standard の可溶性 IL-2 R を用いて作製した標隻曲線と比較して, 可溶性 IL-2 R の量をユニット化して求めた.

\section{3. リンパ球表面マーカー}

リンパ球の表面マーカーはフローサイトメトリー （two color）で調べた．末梢静脈血をへパリン入りで採 血し，Ficoll-Hypaqueに上る比重遠心法により単核球を 分離した. 3 回洗浄後, fluoresein isothiocyanate (FITC) 標識抗 Tac, HLA-DR 抗体 (Becton Dickinson) t加 え,アイスバスの中で 30 分 incubate し, 3 回洗浄し た.さらに, phycoerythrin (PE) 標識抗 Leu 4 抗体を 加え, 30 分 incubate して洗浄したあとFACS tar (Becton Dickinson) で測定した. HLA-DP 抗体につい ては，マウス抗ヒト HLA-DP 抗体を加え，アイスバス の中で 30 分 incubate し，3 回洗浄した. 次に $\mathrm{F}(\mathrm{ab})_{2}{ }^{\prime}$ にした FITC 標識ヤギ抗マウス免疫グロブリン(Cappel) を加えて, 30 分 incubate して洗浄したあと，この 2 次 抗体の Free の Fab の部分があとで加える抗 Leu 4 抗体 と反応するのを block する目的で，正常マウス血清を加 えて15 分 incubate して洗浄した。ささらに PE 標識抗 Leu 4 抗体を加えた.

\section{4. 有意差検定}

有意差検定には Wilcoxon 順位和検定， $\chi^{2}$ 検定を用 Wた.

\section{III. 結 果}

\section{SLE 患者における可溶性 IL-2 R}

図 1 は SLE 患者 40 例, 正常人 10 例の血中可溶性 IL-2 R を測定した結果を示す。正常人では $150.0 \pm 35.0$ $\mathrm{U} / \mathrm{m} l(95 \sim 210 \mathrm{U} / \mathrm{m} l)$ であるのに対し，SLE 患者では $337.8 \pm 188.2(100 \sim 880 \mathrm{U} / \mathrm{ml})$ で正常人に比べ有意に增 加していた ( $p<0.05$; Wilcoxon 順位和検定). 正常人 の mean+2 S.D. 以上を可溶性 IL-2 R 高值群, それ以 下を正常群としてみると，SLE 患者では $40 \%$ の症例が 高值群に属していた。

\section{2. 活性化 $T$ 細胞との関連}

以上の上うに，一部の SLE 患者の血中に高力価の可 溶性 IL-2 R の存在が示されたが,さらにこの高力価の 可溶性 IL-2 R が SLE についても活性化 T細胞の存在を 示唆するものであるかどうか楉討するため，一部の症例 で血中可溶性 IL-2 R と活性化 T細胞の表面マーカーと の関連を検討した，活性化 $\mathrm{T}$ 細胞の表面マーカーとして は，IL-2 R (Tac)，HLA-DR, HLA-DP の3つを用い た. 表1はその結果を示したもので，それぞれの比率 は，T細胞中に占める割合 (Leu $4^{+} \mathrm{Tac}^{+} / \mathrm{Leu} 4^{+}$, Leu $4^{+} \mathrm{HLA}-\mathrm{DR}^{+} /$Leu $4^{+}$, Leu $4^{+} \mathrm{HLA}-\mathrm{DP}^{+} /$Leu $4^{+}$) で示した. Tac 陽性 T細胞, HLA-DR 陽性 T細胞, HLA-DP 陽性 T 細胞は, いすれも IL-2 R 高值群で多い 
表 1 The relationship between soluble IL-2 R and Tac, HLA-DR, HLA-DP positive T cell

\begin{tabular}{lccc}
\hline & Leu4(+) $\begin{array}{c}\text { Tac }(+) \\
/ \text { Leu4 }(+)\end{array}$ & $\begin{array}{c}\text { Leu4(+) } \\
\text { HLA-DR }(+)\end{array}$ & $\begin{array}{c}\text { Leu4(+) } \\
\text { HLA-DP( }(+)\end{array}$ \\
\hline $\begin{array}{l}\text { High value of } \\
\text { soluble IL-2R } \\
(\mathrm{n}=4)\end{array}$ & $4.3 \pm 1.3 \%$ & $30.2 \pm 12.7 \%$ & $58.8 \pm 14.7 \%$ \\
$\begin{array}{l}\text { Normal range of } \\
\text { Soluble IL-2R } \\
(\mathrm{n}=3)\end{array}$ & $2.1 \pm 0.8 \%$ & $26.0 \pm 15.3 \%$ & $46.6 \pm 13.8 \%$ \\
\hline Normal control & $2.0 \pm 0.7 \%$ & $6.3 \pm 2.1 \%$ & $26.6 \pm 8.9 \%$ \\
\hline
\end{tabular}

表 2 Clinical manifestation of patients with high value of free IL-2 $R$ and patients with normal range of free $I L-2 R$

\begin{tabular}{|c|c|c|c|}
\hline & \multicolumn{2}{|c|}{ free IL-2R } & \multirow[b]{2}{*}{ significance } \\
\hline & $\begin{array}{l}\text { high value } \\
(\mathrm{n}=12)\end{array}$ & $\begin{array}{l}\text { normal range } \\
\quad(n=20)\end{array}$ & \\
\hline Malar rash & $91.7 \%$ & $95.0 \%$ & \\
\hline Discoid & 25.0 & 20.0 & \\
\hline Photosensitivity & 45.5 & 31.6 & \\
\hline Oral ulcer & 58.3 & 50.0 & \\
\hline Joint involvement & 91.7 & 95.0 & \\
\hline \multicolumn{4}{|l|}{ Serositis } \\
\hline Pleuritis & 16.6 & 10.0 & \\
\hline Pericarditis & 50.0 & 0 & $\mathrm{P}<0.05$ \\
\hline \multicolumn{4}{|l|}{ CNS } \\
\hline Seizure & 16.6 & 5.0 & \\
\hline Psychosis & 16.6 & 10.0 & \\
\hline $\begin{array}{l}\text { Raynaud's } \\
\text { phenomenone }\end{array}$ & 50.0 & 55.0 & \\
\hline Thrombophlebitis & 0 & 10.0 & \\
\hline $\begin{array}{l}\text { Aseptic bone } \\
\text { necrosis }\end{array}$ & 8.3 & 10.0 & \\
\hline Leg ulcer & 16.7 & 5.0 & \\
\hline Livedo & 16.7 & 15.0 & \\
\hline
\end{tabular}

傾向が認められた.

このことから, 可溶性 IL-2 R 高值の症例では活性化 T細胞の存在することが示晙された.

\section{3. 可溶性 IL-2 R 之臨床所見}

さらに活性化 T細胞の存在を示唆する可溶性 IL-2 R と SLE の臨床像との間に関連性があるかどうかを検討 するために，可溶性 IL-2 R 高值群と正常群で臨床所見 の比較検討を行った．結果は表 2 に示したが，可溶性 IL-2 R 嵪值群では心外膜炎の牘度が有意に高かった $(\mathrm{p}>0.05)$. しかし，蝶形紅斑・ 円板紅斑 - 光線過敏症 口腔内潰傷・レイノーなどの皮膚粘膜症状, 関節症状, 中枢神経障害, 胸膜炎などの他の臨床症状では両者に有
意差はなかった。

次に，検查所見に関して同様の検討を行い，表 3 の結 果をえた. 可溶性 IL-2 R 高值群では抗核抗体の peripheral pattern の頻度が有意に高かった $(\mathrm{p}<0.05)$. し かし，抗 DNA 抗体，抗 RNP 抗体，抗 Sm 抗体などの 抗核抗体の陽性率や，蛋白尿・尿円柱などの腎病変や， 白血球減少・溶血性貣血・血小板减少などの血液病变で は有意差はなかった．また，表には示していないが，補 体価も両群間に差はなかった。

\section{IV. 考案}

T細胞は抗原あるいは mitogen 刺激を受けて, IL-2 を産生すると同時に，細胞表面上に IL-2 R を発現し， 
表 3 Laboratory findings of patients with high value of free IL-2 R and patients with normal range of free $I L-2 R$

\begin{tabular}{|c|c|c|c|}
\hline & \multicolumn{2}{|c|}{ free IL-2R } & \multirow[b]{2}{*}{ significance } \\
\hline & $\begin{array}{l}\text { high value } \\
(\mathrm{n}=12)\end{array}$ & $\begin{array}{l}\text { normal range } \\
\quad(\mathrm{n}=20)\end{array}$ & \\
\hline Hemolytic anemia & $33.3 \%$ & $40.0 \%$ & \\
\hline Leukopenia & 25.0 & 20.0 & \\
\hline Lymphopenia & 83.3 & 85.0 & \\
\hline Thrombocytopenia & 25.0 & 15.0 & \\
\hline \multicolumn{4}{|l|}{ Renal involvement } \\
\hline Cellular cast & 50.0 & 40.0 & \\
\hline $\begin{array}{l}\text { Protein uria } \\
(>3.5 \mathrm{~g} / \text { day })\end{array}$ & 33.3 & 20.0 & \\
\hline \multicolumn{4}{|l|}{ ANA } \\
\hline homogenous & 54.6 & 58.8 & \\
\hline peripheral & 45.5 & 5.9 & $\mathrm{P}<0.05$ \\
\hline speckled & 0 & 35.5 & \\
\hline nucleolar & 0 & 0 & \\
\hline Anti DNA antibody & 100.0 & 94.1 & \\
\hline Anti Sm antibody & 9.1 & 31.3 & \\
\hline Anti RNP antibody & 27.3 & 50.0 & \\
\hline Anti SS-A antibody & 75.0 & 45.5 & \\
\hline Anti SS-B antibody & 12.5 & 0 & \\
\hline
\end{tabular}

それらの相互作用により增殖していくことはよく知られ ている9). また，増殖の過程では IL-2 R のみならず, ト ランスフェリンレセプターあるいは HLA-DR 抗原・ HLA-DP 抗原などの class II 抗原も発現するともいわ れ ${ }^{13,14)}$ ，これらのレセプターや抗原は，活性化T細胞の マーカーとしても使われている. 一方, 最近, IL-2 R は T細胞の増殖の過程で, 細胞表面だけでなく, 培養上清 中や血清中にも存在していることが報告されており11， 細胞表面の IL-2 R のみならす，この可溶性 IL-2 R む活 性化 T細胞のマーカーとなりらる可能性が示唆されてい る.

可溶性 IL-2 R の assay は認識するエピトープの異な った $2 つ の$ 抗 IL-2 R 抗体を用いたELISA法で測定でき るようになっており，それが IL-2R のみを特異的に検 出することもすでに証明されている ${ }^{11)}$. また，死細胞の 遺残などによって検出されるものではなく，細胞から分 泌して出てきたものであることも証明されている ${ }^{11)}$.

可溶性 IL-2 R は特に正常人リンパ球を PHA あるい は抗 OKT 3 抗体などで刺激したあとの培養上清中や11), ATL 患者の血清中に高力価で存在するといわれてい る ${ }^{15)}$ また, $\operatorname{AIDS}^{16)}$, T細胞系の悪性リンパ腫 ${ }^{16)}$, Hodgikin 病 ${ }^{16)}$ の患者の血中にも存在するとする報告が ある.これらの疾患やリンパ球を mitogen 刺激した状
態では，腫湟性に增殖した T細胞あるいは活性化 $\mathrm{T}$ 細胞 の存在が知られており, 可溶性 IL-2 R が活性化 T 細胞 と関連していることが考えられる.

我々は SLE 患者で活性化 T細胞の存在を示唆する報 告がいくつかあることに着目し，SLE 患者40例の血清 中の可溶性 IL-2 R を検索した. その結果, SLE 患者で は，可溶性 IL-2 R の力価が正常人に比べ有意に増加し ており, 正常人の mean+2 S.D. 以上である可溶性 IL$2 \mathrm{R}$ 高值の症例は 16 例 (40\%) にみられた。このこと は,これらの患者において活性化 T細胞が存在している ことを示唆している可能性がある. 一方, SLEのモデル マウスの1つである MRL マウスの血中可溶性 IL-2 R

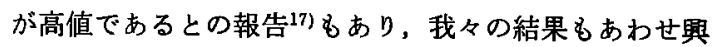
味樑い。たたし，SLE 患者で高值を示した血中可溶性 IL-2 R の力価は, リンパ球の PHA 刺激や ATL 患者に みられる力価 $(1,000 \sim 10,000 \mathrm{U} / \mathrm{ml})$ ほど高くはなかっ た.これは, 我々が今回検索した症例の疾患活動性がそ れほど高くないこと，T細胞の增殖が ATL のように腫 瘍性でないことによるのかもしれない，また，SLEの T細胞では IL-2 R の発現が減少していることが指摘さ れておりこのことも関係している可能性もある.

次に, 我々は可溶性 IL-2 R が SLE 患者においても活 性化 T細胞の存在と関連しているかどらかを確かめるた 
め, 活性化 $\mathrm{T}$ 細胞と関連の樑いリンパ球の表面マーカー (Tac, HLA-DR, HLA-DP) との関係について検討し た. その結果, 可溶性 IL-2 R 高值群では, HLA-DP 陽 性 $\mathrm{T}$ 細胞, HLA-DR 陽性 $\mathrm{T}$ 細胞, Tac 陽性 $\mathrm{T}$ 細胞の比 率はいずれも高い㑯向にあり，可溶性 IL-2 R が活性化 T細胞の存在と関連していることが示唆された。ただ し，これらの表面マーカーが活性化T細胞を直接示して いることは証明されておらず，また，可溶性 IL-2 R が これらのマーカーを持った細胞から出てきたといら証拠 るないため, 今後, IL-2R を発現しているT細胞や他の 活性化 T細胞のマーカーとの関連の検索, cell cycle の 解析も含めて, さらに詳細な検討が必要と思われる.し かし，いずれにしろ，可溶性 IL-2 R が活性化T細胞の 存在とある程度の関連があること，そして，他の活性化 T細胞のマーカーと比べ測定法が簡単なことより，活性 化 T細胞の存在を知る 1 つの指標として臨床に応用でき る可能性もあると思われる.

SLE の活動性や臨床病態の指標として，DNA 抗体を 含む各種抗核抗体，他の自己抗体，血清補体価など多種 あげられる. その中で最も病態とよく相関するものに活 動性ループス堅炎における抗 DNA 抗体高值と血清低補 体価があげられるが，これも全ての症例にあてはまるわ けではない. そのため, 新たな免疫学的指標の検索は常 に必要と思われる.この観点から, 今回, 我々は可溶性 IL-2 R の存在と SLE の臨床像との関連性についてもあ わせて検討を試みた．その結果，臨床症状では心外膜炎 が可溶性 IL-2 R 高值群で有意に多いことを認めたが， それ以外は特に差が認められなかった。また，検査所見 では，抗核抗体の peripheral pattern が可溶性 IL-2 R 高値群で有意に多いことを認めたが, 抗 DNA 抗体, 補 体価などの疾患活動性を示す所見でも差はなかった。こ のことは可溶性 IL-2 R が病像・疾患活動性に関係なく 存在している可能性もあるが, 同一症例の治療経過から
みた可溶性 IL-2 R の変動が観察されていないため, 今 後さらに詳細な検討が必要と思われる.

可溶性 IL-2 R の発現調節・役割については種々の推 察がされているが，いまだに不明である．発現調節に関 しては, 細胞表面の IL-2 R が出てくるという説 ${ }^{18)}$ と m-RNA レベルですでに異なっているといら説 ${ }^{11)}$ がある が，詳細はいまだにわかっていない，また，可溶性 IL$2 \mathrm{R}$ は in vitro で抗原あるいは mitogen 刺激した状悲 では細胞表面の IL-2 R と同時に出現するといわれる $か^{12)}$, 経過を追った研究では，時期によって出現の度合 が異なるという報告もある11). 我々の検索した SLE 患 者においても，高力価の可溶性 IL-2 R が出現している にもかかわらず， T細胞表面の IL-2 R がそれほど増加 していない症例 ( 2 例; 細胞表面の IL-2 R を調べた可 溶性 IL-2 R 高值群の 50\%）もみられ，出現時期の差が 関連しているのかもしれない.

さらに，従来可溶性 IL-2 R はほとんどが T細胞と関 連しているといわれてきたが，B細胞の関与は皆無でな いとの報告も出てきている ${ }^{199}$.すなわち，正常 B細胞を SAC と IL-2 あるいは LPS で刺激すると培養上清中に 可溶性 IL-2 R が出現してくる ${ }^{17,19)}$. そして, 活性化B 細胞も IL-2 R を発現することなども考え合わせると， ポリクローナルにB細胞が活性化していると考えられる SLE では, B細胞由来の可溶性 IL-2 R も無視はできな いと思われる．しかしながら，B細胞由来の可溶性 IL$2 \mathrm{R}$ は T 細胞由来のむのに比べて量的に少ないといわれ

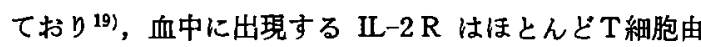
来と考えられるが，活性化したB細胞との関連について 検討が必要と思われる.

本論文の要旨は第 15 回日本臨床免疫学会総会にて発 表した。

献

1) Smolen, J.S., Chused, T.M., Leiserson, W.M. et al. : Heterogeneity of immunoregulatory $\mathrm{T}$. cell subsets in syetemic lupus erythematosus. Am. J. Med., $72: 783 \sim 790,1982$.

2）谷口 修：ヒト免疫異常とリンパ球サブセット異 常. 日臨免誌, 9:398 403, 1986.

3) Smith, J.B., Talal, N.: Significance of selfrecognition and interleukin-2 for immunoregulation, autoimmunity and cancer. Scand. J.
Immunol., $16: 269 \sim 278,1982$.

4) Sakane, T., Steinberg, A.D., Green, I. : Failure of autologous mixed lymphocyte reactions between $T$ and non $T$ cells in patients with systemic lupus erythematosus. Proc. Natl. Acad. Sci U.S.A., 75 : 3464 3468, 1978.

5) Alcocer-Varela, J., Alarcon-Segovia, D. : Decreased production of and response to interleukin-2 by cultured lymphocytes from patients 
with systemic lupus erythematosus. J. Clin. Invest., $69: 1388 \sim 1392,1982$.

6) Horwitz, D.A., Linker-Israeli, M., Bakke, A. et al. : Defective interleukin 2 production in systemic lupus erythematosus: relationship with $\mathrm{T}$ helper cell lymphopenia and depressed interleukin 1 activity. Arthritis Rheum., 25 : S 28, 1982.

7) 村川洋子 - 坂根 剛 - 恒松徳五郎 - 他 : 全身性工 リテマトーデスにおけるインターロイキン 2 の産 生ならびにインターロイキン 2 に対する反応性の 欠陥. アレルギー, $32: 386 \sim 391,1983$.

8) Hirano, T., Hashimoto, H., Okumura, K. et al. : The appearance of $\mathrm{Ia}^{+} \mathrm{T}$ cell in systemic lupus erythematosus. Cellular, Molecular and Genetic Approaches to Immunodiagnosis and Immunotherapy, 1987, pp. $441 \sim 445$.

9) Smith, K.A. : T-cell growth factor. Immunol. Rev., $51: 337 \sim 357,1980$.

10) Tsudo, M., Uchiyama, T., Yodoi, J. et al. : Failure of regulation Tac antigen/TCGF receptor on adult $T$ cell leukemia cell by antiTac monoclonal antibody. Blood, $61: 1014 \sim$ 1016, 1983.

11) Rubin, L.A., Boutin, B., Nelson, D.L. et al. : Soluble interleukin 2 receptor are released from activated human lymphoid cells in vitro. J. Immunol., $135: 3172 \sim 3177,1985$.

12) Reske-kunz, A.B., Osawa, H., Diamantstein, T. et al. : Soluble interleukin 2 receptors are released by long term cultured insulin-specific
$T$ cells transiently after contact with antigen. J. Immunol., $138: 192 \sim 196,1987$.

13) Trowbridge, I.S., Omary, M.B. : Human cell surface glycoprotein related to cell proliferation is the receptor for transferrin. Proc. Natl. Acad. Sci. U.S.A., $78: 3039 \sim 3043,1981$.

14) Ko, H.S., Fu, S.M., Winchester, R.J. et al. : Ia determinants on stimulated human $\mathrm{T}$ lym. phocytes. J. Exp. Med., 150 : 246 255, 1979.

15) Mackeen, L., Hinuma, Y., Purtilo, D. et al. : Serum interleukin 2 receptor as marker for active $\mathrm{T}$ cell malignancies. Fed. Proc., 45 : 454, 1986.

16) Nelson, D.L. : Soluble interleukin-2 receptors: Analysis in normal individuals and in certain disease states. Fed. Proc., $45: 377,1986$.

17) Balderas, R.S., Diamantstein, T., Theofilopoulos, A.N. et al. : Elevated titers of cell-free interleukin 2 receptor in serum of lupus mice. J. Immunol., $139: 1496 \sim 1500,1987$.

18) Osawa, H., Josimovic-Alasevic, O., Diamantstein, $\mathrm{T}$. : Interleukin 2 receptors are released by cells in vitro and in vivo $I$. Detection of soluble $\mathrm{IL}-2$ receptors in cell culture supernatants and in the serum of mice by an immunoradiometric assay. Eur. J. Immunol., 16 : $467 \sim 469,1986$.

19) Nelson, D.L., Rubin, L.A., Boutin, B. et al. : An analysis of the cellular requirements for the production of soluble interleukin-2 receptor in vitro. J. Clinical. Immunol., $6: 114 \sim 120,1986$. 